\title{
English Textbooks for Teaching and Learning English as a Foreign Language: Do They Really Help to Develop Communicative Competence? ${ }^{1}$
}

Luis Fernando Gómez-Rodríguez

Profesor, Departamento de Lenguas,

Universidad Pedagógica Nacional, Bogotá,

D. C., Colombia.

Miembro del grupo de investigación

en hipermedia, evaluación y enseñanza

del inglés.

lfgomez@pedagogica.edu.co

lfgomez@ilstu.edu

\section{Abstract}

Communicative texts are educational materials for language learning that focus on the genuine use of a language for communicative purposes in a variety of meaningful contexts. Above and beyond the mere study of linguistic forms, these texts offer opportunities to communicate, interact and negotiate meaning.

Three common types of English language practice are analyzed in this article: mechanical practice, meaningful practice and communicative practice. Five English texts representative of those currently used in Colombia were selected to determine to what degree they include genuine communicative tasks and, in this respect, how they encourage the development of communicative competence.

The extent of communicative practice these texts offer students of English was found to be less than the amount of mechanical and meaningful practice. This information should be useful for training English teachers, particularly those who generally focus their classroom activity on the use of texts. Methodological suggestions are offered, based on the results of the study.

Key words

Educational material, language teaching, development of skills, bilingualism, communicative competence (Source: Unesco Thesaurus)

$1 \quad$ This article is the result of a research project I conducted in a TESOL course offered by the Department of English at Illinois State University, USA. One of the topics of the course was the evaluation and analysis of instructional materials in EFL teaching. I want to thank Doctor Aaron Smith for monitoring this study.

Recepción: 2009-09-16 | Aceptación: 2010-09-03

ISSN 0123-1294 | Educ.Educ. Vol. 13, No. 3 | Septiembre-diciembre de 2010 | pp. 327-346 


\section{Textos en inglés para el aprendizaje y la enseñanza del inglés como lengua extranjera: ¿realmente ayudan a desarrollar la competencia comunicativa?}

\section{Resumen}

Los textos comunicativos son una clase de material didáctico para el aprendizaje de las lenguas, que presentan uso real del lenguaje con propósitos comunicativos, dentro de una gran variedad de contextos significativos. Ofrecen oportunidades de comunicación, interacción y negociación de significado, más que el simple estudio de formas lingüísticas. En el artículo se analizan tres tipos comunes de práctica de la lengua inglesa: práctica mecánica, práctica significativa y práctica comunicativa. Se escogieron cinco textos representativos de inglés, que en la actualidad se implementan en Colombia, con el fin de determinar hasta qué punto incluyen tareas comunicativas auténticas, y en este sentido, cómo fomentan el desarrollo de la competencia comunicativa.

Se demostró que el nivel de práctica comunicativa que tales textos ofrecen a los estudiantes de inglés es inferior a las prácticas mecánica y significativa. Esta información intenta ser de gran utilidad para los procesos de enseñanza de los profesores de inglés, en especial para aquellos que por lo general centran sus clases en el uso de textos. Se proponen sugerencias metodológicas, teniendo en cuenta los resultados obtenidos.

\section{Palabras clave}

Material didáctico, enseñanza de idiomas, desarrollo de las habilidades, bilingüismo, competencia comunicativa (fuente: Tesauro de la Unesco).

\section{Textos em inglês para a aprendizagem e o ensino de inglês como língua estrangeira: eles realmente ajudam a desenvolver habilidades de comunicação?}

\section{Resumo}

Os textos comunicativos são uma classe de materiais para aprendizagem de línguas, mostrando o uso real da linguagem para fins comunicativos em diversos contextos significativos. Proporcionam oportunidades de interação, comunicação e negociação do significado, ao invés de um simples estudo de formas lingüísticas.

No artigo se discutem três tipos de prática da língua inglesa: mecânica, significativa e comunicativa. Se escolherem cinco textos representativos de inglês, utilizados na Colômbia actualmente, a fim de determinar o grau em que incluem verdadeiras tarefas comunicativas e, neste sentido, como incentivam o desenvolvimento da competência comunicativa. Foi demonstrado que o nivel de prática comunicativa que tais textos oferecem aos estudantes de inglês é menos do que as práticas mecânica e significativa. Esta informação deve ser útil nos processos de ensino-aprendizagem dos professores de inglês, especialmente para aqueles que costumam concentrar suas lições no uso de textos. Com base nos resultados obtidos, se propõem sugestões metodológicas.

\section{Palavras-chave}

Materiais didácticos, ensino de línguas, desenvolvimento de competências, bilingüismo, competência comunicativa, (fonte: Tesauro da UNESCO). 
This article examines a series of five communicative textbooks that are being used currently to teach English as a foreign language (EFL) in Colombia and are regarded as major resources to help students develop communicative competence. It will be determined whether or not these instructional materials offer learners solid communicative activities to strengthen their opportunities to become communicatively competent. The criterion for evaluating the textbooks in question is based on the three types of language practice (mechanical, meaningful, and communicative) proposed by Jack Richards (2005). According to him, these practices advocate communicative language learning in the EFL context.

Razmloo (2007:127) claims the affluence of published materials now available on the market makes selection of the right textbooks a challenging task. Hence, examination of the communicative level of the English texts chosen for this article is intended to make English teachers aware of the methodological strengths and weaknesses these kinds of instructional materials have. English teachers will also realize to what extent they can rely on textbooks in their daily teaching practice. Likewise, they will learn key specifications that will enable them to make wise decisions when it comes to selecting, evaluating, and implementing English textbooks at the institutions where they work.

\section{Theoretical Considerations}

Over the last four decades, Communicative Language Teaching (CLT) has been recognized as an ideal approach to help learners acquire a foreign language. The new directions in the theory of language proposed by Chomsky helped CLT to emerge. According to Richards and Rodgers (2006), Chomsky recognized the current standard structural theories on language as being incapable of accounting for the fundamental characteristics of language; namely, the creativity and uniqueness of individual sentences. Since CLT is a teaching language approach that mainly sees language as a system for communication, it attempts to develop communicative competence.

Communicative competence is a term introduced by Hymes (1972), who defined it as the ability to convey and interpret messages and to negotiate meaning with other speakers in specific contexts. Over the years, the term has been discussed and redefined by many authors, such as Canale and Swain (1980), Savignon (1997, 2001), and Bachman (1999). The notion of communicative competence centers primarily on the negotiation of meaning in real situational contexts. In this respect, Canale and Swain (1983) distinguished four categories that define the notion of communicative competence. The first two refer to use of the linguistic system: grammatical competence and discourse competence. The former allows speakers to know and understand the appropriate use of language forms. Without knowledge of the linguistic code, communication would be absolutely impossible. The latter is every speaker's ability to connect sentences in a meaningful and coherent discourse. The third category is socio-linguistic competence, which involves knowledge of the socio-cultural rules of language and the discourse in which language is used. It embodies the ability to understand the context or situational reality in which we communicate something meaningful. The fourth category is strategic competence, which refers to the verbal and nonverbal communication strategies speakers use to compensate for breakdowns in communication due to insufficient levels of competence. In other words, speakers are able to use strategies to compensate for an imperfect knowledge of rules and a lack of vocabulary in the communicative process. Paraphrasing, repeating, and guessing are examples of strategic verbal competence. Gestures, mimicking, and body positions are examples of strategic nonverbal competence. All these strategies are valid when learners intend to negotiate meaning.

Canale's and Swain's theory of communicative competence was modified in a more detailed way by Bachman (1991). He places grammatical competence and textual competence in a category called organizational competence to allude to the entire linguistic system of language formation, such as the connection among sentences to form longer discourses. Bachman also divides 
pragmatic competence into two subcategories: illocutionary competence, which deals with the act of receiving/ sending intended meanings in normal interaction, and socio-linguistic competence, which involves aspects of politeness, dialects, figures of speech, and cultural manifestations. Bachman does not include strategic competence in his classification. He categorizes it as a separate element of communicative language ability, specifically one that helps learners to compensate for communication during the process of meaning negotiation.

Later, Byram (1997: 8) explained that Hymes, the initiator of the concept of communicative competence, prompted an awareness of the relationship between linguistic and socio-cultural competence. In fact, Hymes described linguistic competence as just one kind of cultural competence. He stated that children "develop a general theory of speaking appropriate in their community, which they employ, like other forms of tacit cultural knowledge in conducting and interpreting social life" (Hymes, 1972: 279). In citing Hymes, Byram said the teaching of foreign languages has been concerned more with the linguistic development of language than the cultural implications language brings about. This is because language teaching has been influenced largely by linguistic analysis, leaving out cultural competence. For that reason, Byram restated and complemented the notion of communicative competence as Intercultural Communicative Competence in an attempt to rescue the substantial presence of the cultural dimension that language contains. Byram (1997:22) remarked that foreign language teaching should concern itself not only with the practical questions of linguistic competence for communication, but also with the relationship between the language and the cultural practices and beliefs of a particular group. Accordingly, it is essential to recognize that competence in a foreign language also implies the acquisition and recognition of cultural practices. Therefore, the most complete term Byram proposes is intercultural communicative competence.

Savignon (2001: 8) also contributed to the definition of communicative competence (or intercultural communicative competence) by stressing that communicative competence is relative and depends mainly on the cooperation of all participants, because it is a very dynamic conception in which at least two individuals are involved in the process of negotiating meaning.

The Common European Framework of Reference for Languages: Learning, Teaching, Assessment (CEFRL) refers to the properties of communicative competence in much the same way:

Language use, embracing language learning, comprises the actions performed by persons who are individuals and as social agents develop a range of competences, both general and in particular communicative language competences. They draw on the competences as their disposal in various contexts under various conditions and under various constrains to engage in language activities involving language processes to produce and/or receive texts in relations to themes in specific domains, activating those strategies which seem most appropriate for carrying out the tasks to be accomplished"( 9 ).

This idea suggests that language competence is the ability that allows learners to establish successful communication in a foreign language, in genuine contexts, and through everyday tasks found in real life. Being competent implies more than knowing the linguistic code; it also necessitates being able to negotiate meaning and to interact socially in the target language.

Theforegoing perspectivesontheconceptof intercultural communicative competence lead us to consider the principles of CLT as being the following:

- Learners developtheir ability to communicate in genuine contexts, since contextualization is a basic need. Language in context, as Byram explains, contains cultural traits.

- The contents of a language course are based on social communicative functions and not merely on linguistic structures.

- $\quad$ Students work in groups to establish meaningful negotiation when they are involved in role-playing activities, problem-solving tasks, dramatizations, and simulations of situations in real life. 
- $\quad$ Classroom materials and activities are authentic, as they reflect typical real-life situations.

- Language is created by the individual, frequently through trial and error. Hence, making mistakes is part of the learning process.

As noted earlier, CLT attempts to develop communicative language competence. Therefore, one would expect communicative textbooks to be designed to provide the means to enhance it. For the purpose of the study presented in this article, I will concentrate primarily on the concept of communicative competence, rather than on the concept of intercultural communicative competence. In other words, I will focus on an analysis of the mechanical, meaningful, and communicative practices included in English textbooks. For the sake of clarification on this point, a description of the nature of communicative textbooks is provided below.

Razmloo $(2007,134)$ reports that Jack Richards, an influential author and textbook designer, was asked in an interview to list which principles he took into account when designing EFL communicative textbooks. Richards replied by saying that textbooks need to make communication the focus of language learning. In his opinion, textbooks must create opportunities for interaction and the negotiation of meaning through the use of information sharing, problem solving, and role-play activities. Textbooks should link the different skills of speaking, reading, listening, and writing, and ought to link the learning of grammar to communicative tasks.

In addition to the communicative role Richards assigns to textbooks, other authors also believe that authenticity is a major feature. Kramsch (2001: 177) claims the term "authentic" has been used as a reaction against the prefabricated artificial language of textbooks and the dialogues implemented in language classrooms. However, research conducted by Berry (2000) and Kim and Hall (2002) found there has been little change in the authenticity of communicative language samples for communicative purposes. Authenticity refers to the way language is used in communication to fulfill a social purpose in a particular context. Therefore, it is important to bear in mind that bringing authentic material into the classroom demands the teacher be prepared peda- gogically to create tasks in which such material becomes purposeful in simulated situations of everyday life. For instance, genuine menus from restaurants could be used as authentic reading material to place students in a situation where they are asked to order food. The same applies to the use of a telephone book as authentic material from which students can derive information about somewhere they plan to go. Classified ads also can be ideal material for simulated telephone conversations in which students order or sell various items. Dammacco (2010) provides examples of authentic materials, such as menus, travel brochures, and recipes, as appropriate resources for working with real language. From there, learners can move gradually to more advanced texts, such as newspapers, magazine articles, and fiction.

These theoretical considerations posed by CLT, the CEFRL, and scholars have obliged all professionals involved in second language teaching to think about how they actually help learners to become communicatively competent. As a result, a radical reevaluation of syllabus designs and English communicative textbooks is underway in the field of language teaching. In its introductory chapter, the CEFRL says it "provides a common basis for the elaboration of language syllabuses, curriculum guidelines, examination, textbooks, etc" and describes "what learners have to learn to do in order to use a language for communication" (1). In light of these ideas, it is essential to determine if current communicative English texts, which happen to be the main instructional material used by teachers and students in EFL classrooms, truly help learners to develop communicative competence. However, before doing so, it is important to keep in mind the following aspects.

\section{The Research Question for this Study}

Learners are expected to develop their communicative competence by using English textbooks as a main resource. Therefore, we seriously should consider whether or not communicative 
textbooks possess the characteristics that are necessary to help students acquire a foreign language. The question is: Do EFL textbooks include authentic language activities set in meaningful communicative situations to enhance communicative competence? To arrive at an answer, this comparative study analyzed five representative EFL textbooks currently being used to teach English in Colombia. The names of the textbooks will not be revealed. They will be labeled with the letters A, B, C, D, and E, so as to keep them anonymous and to avoid influencing the reader with any preconceptions that might be created about the textbooks evaluated in this study. However, readers will be able to implement the procedure explained below to critically review the textbooks they use with their learners.

\section{Characteristic of EFL Textbooks}

Many scholars indicate that textbooks seem to be the main teaching resources in EFL classrooms. Patricia Byrd (2001: 415) claims most teachers depend on textbooks - often as a required tool - because they provide content and activities that shape what happens in the classroom. González (2006: 104) says textbooks became an alternative for three main reasons: they are apparently eclectic alternatives to save time and money, they include pictures and graphic materials that may be more efficient than the teacher's descriptions, and they contain all kinds of objects that may be difficult to bring into the classroom. EFL textbooks are, indeed, a major necessity for most teachers, because the bulk of them feature an eclectic approach based on the current theories proposed by communicative trends. For instance, Task-based approach engages learners in problem-solving tasks. Contentbased approach also offers opportunities to deal with interesting topics and subject matter, rather than coping with grammar-oriented lessons. Moreover, collaborative learning encourages students to work in groups, as an ideal way to exchange information socially and meaningfully. According to Richards and Rodgers (2006), textbooks are designed in such a way that their tables of contents suggest a gradual development of language forms and functions, going from the most basic to the most complex. All these approaches and features are intended to develop the use of communicative language. However, despite considerable effort on the part of text designers, editors, and publishing houses, a range of grammar-oriented activities and mechanical practice continues to prevail. As a first step, it is crucial to differentiate the three main types of language practice found in most English instructional materials, according to Richards: (2005: 15):

1. Mechanical practice refers to controlled activities that involve repetition and substitution drills. They are designed to practice the use of particular grammatical items (2005: 15). In many textbooks, this practice demands sentence completion (usually with grammar activities in isolation), but lacks authentic language negotiation.

2. Meaningful practice refers to activities in which language still is controlled and "students are required to make meaningful choices when carrying out practice" (2005: 15).

3. Communicative practice embodies those activities in which language "is not totally predictable." Language production at this level is more spontaneous and authentic, because meaning negotiation takes place "within a real communicative context" and "real information is exchanged" (2005: 15).

These three types of language practice essentially define the kinds of activities often featured in communicative textbooks. All three are expected to be included in the methodological sequence of the various units that constitute English textbook, mainly because students need to go through a process of controlled-practice, by first working on easy-guided mechanical activities, before eventually reaching a degree of free language practice that embraces communicative interaction.

Therefore, if textbooks are designed to develop language competence, one can assume they should contain a well-balanced number of activities pertaining to the three types of language practice described above. To confirm this assumption, we will determine if the five EFL textbooks chosen for this analysis truly provide 
opportunities to negotiate meaning in different contexts, based on the notion that most of the activities are contextualized in situations where, as Richards (2005: 15) suggests, real information is exchanged. As English teachers, we need to be aware of the frequency of these types of practice in English textbooks, in order to be sure the classroom material we use is effective for our communicative purposes. Also, it is important for us to undertake a critical evaluation of textbooks with an eye towards improving our teaching practices. Therefore, let us determine if the three language practices previously listed are well-balanced in the textbooks we often use to teach English. To begin with, I will explain the procedure that was used to analyze the five selected textbooks.

\section{Data Analysis}

1. Five representative English textbooks were selected for this analysis. The criterion for their choice was based on the fact that they are currently used for upper secondary and university instruction and are offered by recognized publishing houses. They are employed in classrooms where the main goal is to develop communicative competence.

2. Three representative units from each of the five EFL textbooks were chosen to examine the three types of practice proposed by Richards for CLT; that is, mechanical, meaningful, and communicative practice. Three units were selected as representative data for each textbook, since all the units included in each book follow a model pattern. In other words, all the units include the same sections, approximately the same number of activities, and the same types of practice based on a unit model that publishing houses often provide to designers and authors. Accordingly, it was not necessary to take data from all the material, since the same pattern is repeated in all the units of the textbooks.

3. The activities in each unit were classified in a table, pursuant to the categories of mechanical, meaningful, and communicative practice. They also were categorized with respect to the four communicative skills: reading, listening, speaking, and writing, plus grammar and vocabulary. (See the data collection instrument in Appendix 1)
4. The number of activities classified in relation to each type of practice was tallied and averaged per unit (see Appendix 1). The data collected clearly show which practice is used more often in the textbooks and which is used less. The figures also show which communicative skills are practiced the most and which are practiced the least.

5. All the data were obtained as indicated. (Table 1).

The average percentage of mechanical, meaningful, and communicative practice per unit is summarized and included in the table below, along with the average percentage of each type of practice in the textbook as a whole. (Table 2).

1. The following are the results for Textbook A, which was the first one analyzed:

Out of the sample of the units in Textbook A, 50.12\% include a high number of mechanical activities, $42.5 \%$ involve meaningful practice, and only $7.31 \%$ focus on real communicative practice.

2. The following results were obtained for Textbook B:

In all, $37.73 \%$ of the activities are mechanical practice, $43.65 \%$ are meaningful, and only $22.10 \%$ are communicative practice. These proportions are shown graphically below.

3. The results for textbook $C$ are similar:

More than half the activities included in Textbook C (55.69\%) pertain to meaningful practice. Mechanical practice ranks second, with $22.39 \%$, and communicative practice, as in the aforementioned textbooks, is lower and accounts for only $15.90 \%$.

4. Textbook D showed a variation. The most frequent practice activities are mechanical, with $48.48 \%$, which is almost half the book. The second most common activity is meaningful practice, with $28.62 \%$. As in textbooks A, B and C, communicative practice accounts for the lowest proportion, with only $22.93 \%$.

5. Textbook E was the last one analyzed and also reflects a difference. Meaningful practice accounts for the largest average share, with $54.75 \%$, 
followed by communicative practice, with $34.89 \%$, and mechanical practice, with $10.3 \%$.

The following table broadly summarizes the three types of language practice developed in the five Englishlanguage textbooks examined for this study. (Global Average for all the Textboooks).

\section{Results}

\section{With respect to mechanical practice}

The results show Textbook $A$ is the most grammaroriented, with mechanical practice accounting for $50.12 \%$, while the least grammar-oriented is Textbook E, with only $10.3 \%$ grammar practice. The data also reveal that Textbook D occupies second place, with a high degree of mechanical practice (48.48\%). Textbooks A and D are the two with the largest amount of mechanical practice. We can conclude from the data that only two of the five textbooks: A and D, are characterized primarily by a large degree of mechanical language practice, while B, C, and E tend to be more communicative.

The following is an example of mechanical practice in one of the textbooks. Learners are asked to compose sentences in isolation, without a relevant context. By in large, it features a repetition drill model:

Complete the prompts in bold, using the present perfect and just or never, as in the examples.

- I can't sleep in here. I/ not sleep/ tent.

- I've never slept in a tent before.

- They are very happy. They/have/baby.

- They've just had a baby.

- Who is that woman?

- This is my new dress.

- I'm not hungry.

- Mom is angry with John.

\section{I/ not see her/ before.}

I/ buy it.

I/ have/ lunch.

\section{$\mathrm{He} /$ break/ window.}

\section{With respect to meaningful practice}

Textbook $D$ has the least amount of meaningful practice: only $28.62 \%$, while Textbook C has the most: $55.69 \%$. However, according to the data, there is no major difference between textbooks $\mathrm{C}$ and $\mathrm{E}$ with respect to meaningful practice, and both provide learners with more than $50 \%$ of meaningful language use. As for to textbooks A and B, they provide a moderate proportion of meaningful practice: between $42.5 \%$ and $43.65 \%$; in other words, less than $50 \%$ of the language practice is meaningful practice. Moreover, it is important to emphasize that although the proportion of meaningful practice in Textbook $A$ is $42.5 \%$, it contains more mechanical practice than meaningful practice, which suggests that it could be classified as not essentially communicative.

This is an example of meaningful practice taken from one of the textbooks. It requests learners to answer several questions about a girl's personal information. It is a meaningful activity in a context. However, the context is quite limited. The instructions should offer more contextualization to make the activity more relevant. Language is controlled, seeing as it focuses on simple present tense usage.

Listening: Listen and find this information.

a. What is the girl's name?

b. What does she want to be?

c. Where does she live?

d. What is unusual about her day?

The following example also is a type of meaningful practice. It provides a context, and learners are required to make choices to complete a story. The language is controlled as well, because it focuses on the correct use of simple past tense. Although the language is placed in a context, it is important to consider whether it is truly meaningful to the learner.

Read the text and put the verbs into the past simple.

Tom Stevens 1. (live)

on a big farm. He 2. (have) in the country hood, but he 3. (want) a happy childworld. When Tom 4. (leave) to see the (decide) to join the Navy...

\section{With respect to communicative practice}

As illustrated, all five textbooks provide limited opportunities for communicative practice. Textbook $\mathrm{E}$ includes the most communicative 
practice, $34.89 \%$, while opportunities for communicative interaction in the others amount to less than $23 \%$. Textbook A provides the fewest opportunities for communicative practice $(7.31 \%)$.

The following is an example of communicative practice taken from one of the textbooks. It provides a meaningful context, because learners are asked to choose their favorite sports star. Although it suggests that learners make wh questions, the language is not totally predictable, because it allows learners to make their own decisions. Also, language production is more spontaneous and authentic, since learners are required to interview a classmate and, thus, engage in a process of meaning negotiation in a real communicative context where real information is shared. After the interview, learners are asked to write a report.

\section{An Interview}

a. Choose a sports star

b. Make six questions to ask the sports start. (Use how, what, when, where, do, why.)

c. Do your interview with a partner.

Follow up: Write your interview with the sports star. The overall analysis shows Textbook $\mathrm{E}$ tends to be meaningful for the most part, because there is less concentration on mechanical practice (10.3\%), while the rest of the language practice accounts for $89.64 \%$. However, Textbook E has more meaningful practice than communicative practice. Textbook $\mathrm{C}$ ranks second, with a limited degree of mechanical practice (28.39\%). Yet, like Textbook E, it also offers more meaningful practice than communicative practice. Textbooks B and D are not entirely communicative, but they can be classified as meaningful. Textbook $A$ can be classified as oriented towards mechanical practice, since $50.12 \%$ of the activities are grammar-based.

Given the results, the conclusion is that the most common type of language practice in English textbooks is meaningful. In other words, students are required to make meaningful choices, and language production in activities of this sort continues to be controlled. However, when examining the textbooks in question, it was determined that many of the meaningful activities are not, in fact, authentic tasks in authentic contexts. They are meaningful in the sense that students are able to make choices and play with the language, but opportunities to use real language are not completely achieved. Most of these activities are displayed on formats such as those for matching exercises, multiple choice items, true and false statements, filling in the blanks, ticking the correct answer, and making sentences. These kinds of activities obviously are an excellent way to begin mastering a foreign language, but the disadvantage is rooted in the fact that meaningful practice accounts for $44.44 \%$ of thefivetextbooks as a whole. This reduces opportunities for more communicative practice. Although students do learn to play with the language and are challenged to use different cognitive strategies to make correct choices, the language still is highly controlled and predictable. Moreover, some of the activities are very easy to answer and are not especially challenging when it comes to promoting communication.

The results also show mechanical practice continues to account for a high proportion of the textbooks that supposedly were designed on a communicative basis. Surprisingly, $34.88 \%$ of all language practice is not as communicative as was expected. The activities and exercises classified as mechanical practice consist of substitution drills and repetition of model sentences, which are perfunctory techniques used to memorize grammar patterns. So, real communication is not facilitated by these activities.

As illustrated, only $20.66 \%$ of all the activities included in the textbooks can be considered communicative practice. Task-based exercises such as writing e-mails, letters, and reports, having informal conversations, giving oral presentations, role-playing, interviews, and working on projects, are fewer compared to the amount of mechanical and meaningful practice.

The results point to one main conclusion. Although it is reasonable to expect a careful methodological procedure for learning a foreign language to contain the three types of language practice, communicative textbooks should offer 
a better balance in the number of activities per unit, if real communicative competence is the main goal. The study suggests that communicative competence cannot possibly be attained if the emphasis is on mechanical and meaningful practice. Textbooks should include more communicative practice to give students an opportunity to negotiate meaning and to produce spontaneous language on a genuinely communicative basis.

The fifteen data collection sheets (see the sample in Appendix 1) provided additional, relevant information on how textbooks deal with practice in communicative skills (reading, listening, speaking, and writing), plus grammar and vocabulary. To obtain the results presented below, the activities used to develop each skill were tallied to determine which skills are practiced more with these textbooks. (Language Skills, Grammar, and Vocabulary)

Grammar and reading skills are practiced the most, with $22.04 \%$ each. Speaking, with $21.50 \%$, ranks third. Listening accounts for $15.32 \%$ of all language practice and vocabulary, $13.17 \%$. Writing is practiced the least, with only $5.91 \%$. Based on this data, it is possible to conclude that the communicative textbooks in question need to facilitate more meaning negotiation in real or simulated situations of everyday life. This means textbooks should reduce the amount of grammar-oriented activities and incorporate more practice of the four language skills, in addition to increasing the number of tasks that are more authentic. The broad emphasis on grammar activities in the textbooks evaluated for the study raises the question as to whether or not they actually help learners to develop communicative competence.

The considerable amount of practice in reading and speaking skills featured in these same textbooks is worth mentioning. Some of the reading activities lack authentic reading resources. In the case of reading material, Brown (2009: 243) says textbooks in general claim to supply a wide range of reading on different topics. However, while the range of topics in these textbooks is reasonable, the variety of material is limited. Too many textbooks feature mostly magazine-style reading passages, while ignoring news reporting, prose fiction, poetry and other genres. As the study detected, the five textbooks in question lack authentic readings. Roldán and Serrato (2009: 196) discovered similar findings in a studied carried out in Spain. They wanted to determine to what extent there is a correlation between the descriptors corresponding to the levels of competence proposed by the CEFRL and the contents of three textbooks commonly used in many countries. They concluded that readings generally are deficient in the number of authentic materials used for reading comprehension tasks. For instance, some textbooks ignore advertisements, menus, and manuals; that is, material students normally would use in real life to accomplish actual tasks. Consequently, seeking extra reading material other than the magazine-style language presented in most EFL textbooks is a pending task for instructors, if they are to offer learners additional reading resources normally found in real life.

With regard to the other language skills, the aforementioned study shows it is necessary to increase the number of listening activities in textbooks, as is also the case with writing, which is a very productive skill. Furthermore, listening and writing activities should include more authentic input that is designed to involve learners in meaningful tasks. In short, the results indicate this type of language practice oftentimes does not feature complete meaning negotiation.

A third aspect to be analyzed on the basis of the information gathered for this study concerns the use of formats. Formats refer to the different ways in which language is organized and presented in different activities, so students can make choices and interact with, play with, and use language. These results are important because they show the type of activities and formats EFL students frequently are given when they work with textbooks. The following list includes the more usual formats employed in communicative English texts. (Table 3)

The five textbooks examined for this study tend to include formats that do not reflect real communicative and authentic tasks. Repetition, formal grammar study, drilling activities, and 
matching are the most common exercises for mechanical practice. Other formats in this category include correcting statements, checking the correct answer, finding the mistake, and translating. Meaningful practice features formats such as answering questions, matching activities, filling in the blanks, and multiple choice questions; however, they are not entirely authentic. Other formats involve playing games, putting events in order, and writing questions. Also, authentically communicative activities are not practiced often. There is a limited set that includes dialogues, writing letters and e-mails, answering open-ended questions, and exchanging ideas and opinions through small talk.

The analysis of the formats implemented with respect to each type of language practice also shows the development of communicative competence is at risk because there are few real communicative activities. Repetition, grammar study, drilling activities, and matching do not guarantee learners will become competent. Therefore, the implication is that textbooks should include additional activities through which real language negotiation can take place. Once again, it is relevant to say that mechanical and meaningful activities based on these formats are pedagogically correct as part of the learning process, but an increasing amount of emphasis should be placed on communicative practice.

\section{Conclusions}

The study of the five English textbooks demonstrates they cannot be relied on entirely to develop communicative language competence, because of the following reasons:

- In terms of the type of language practice, they do not include enough communicative activities and lean heavily towards mechanical and meaningful practice. Social communicative interaction and meaning negotiation through real, contextualized activities account for only $20.66 \%$ of language practice as a whole.

- In terms of language skills, they give more importance to grammar study and grammar practice than to practice concerning the four communicative skills (reading, listening, speaking, and writing). Consequently, these textbooks are relatively more grammar-oriented than skill-based.
- In terms of formats, the textbooks in question focus more on the use of formats that do not reflect authentic tasks. Filling in the gaps, drilling, repetition, multiple choices, and matching, among other exercises, are appropriate to manipulate information and to make language choices, but should be complemented with other possibly meaningful and memorable tasks that are part of what speakers do in real life.

The study revealed other elements that were not part of the research question, but are important to point out, namely:

- The answers in many of the activities are very predictable.

- $\quad$ The exercises need to be more challenging; some are obvious.

- $\quad$ Language practice activities are quite short. More practice is needed.

- $\quad$ Some units become predictable and monotonous, since they follow a repetitive pattern.

- The thematic sequence and story line of some units need more coherent development.

On the other hand, the texts in question offer several advantages that are worth mentioning:

- Most of the activities tend to be contextualized (not all of them).

- There is a wide variety of formats and activities.

- The grammar focus and its relation to communicative functions are coherent and well-developed in each unit.

- The textbooks, in general, are visually attractive and motivate students to learn.

- $\quad$ For the most part, creativity is one of the strong points in the design of these texts.

- The themes are appropriate for the target population.

- The texts are designed carefully, based on a methodological procedure that includes warm up, study, activation, and production. They also follow a sequence that moves from receptive skills (reading and listening) to productive skills (speaking and writing). 
- $\quad$ Several of the textbooks embrace cross-cultural aspects and, therefore, promote intercultural awareness.

\section{Final Considerations}

If foreign language learners are meant to develop communicative competence, as the communicative approach and the CEFRL suggest, some significant changes in communicative texts are needed. The attempt to design better English textbooks should continue. These materials must help learners to use authentic language on a genuinely communicative basis. So far, EFL textbooks have yet to include more communicative practice to effectively enhance communicative language competence.

Consequently, in addition to textbooks, English teachers should use complementary instructional materials to help students achieve communicative language. Lidikó Lázár and Christian Peck (2007:16) suggest some authentic activities to develop intercultural communicative competence, such as involving learners in short presentations, role-playing, project work, ethnographic tasks (doing interviews and conducting observations), games, and small group discussions. This raises awareness of cultural differences and helps to understand the importance of those differences when learners are engaged in the process of communication. These types of authentic activities reflect task-based instruction.

The incorporation of simple authentic readings from comics, newspaper ads, magazine articles, and literary pieces, such as poetry and short stories, can be significant resources that give learners an opportunity to develop reading skills through the use of authentic materials. The CEFRL describes what language learners must learn to be able to use a language for communication. In Chapter 4.3, it states that one of the various ways to enhance communication with other interlocutors is through the implementation of aesthetic uses of language.

Imaginative and artistic uses of language are important both educationally and in their own right. Aesthetic activities may be productive, receptive, interactive, or mediating and may be oral or written. They include such activities as ... the production, reception and performance of literary texts, e.g., reading and writing texts (short story, novel, poetry, etc) (56).
In relation to short stories, Hsiu-chin (2008:47) points out that some researchers advocate the use of picture storybooks and short stories as rich resources for EFL teachers to introduce vocabulary and sentence structures in a memorable and meaningful context. They also have the potential to transfer EFL learners from mechanical language learning to a context that implies more personal involvement.

Other types of authentic materials that complement the communicative practice found in $\mathrm{EFL}$ textbooks are movies and popular songs, as well as television and radio programs. These are useful task-based materials that are part of the everyday activities we normally engage in. As for practicing writing skills, it is suggested that teachers work increasingly with diaries, e-mails, text messages, and story writing. An example worth mentioning is the one suggested by Shekary and Tahririan (2006:557), who believe instructors should involve students in text-based on-line chats or computer mediated communication. The production of text on line has demonstrated that learning English requires more than knowing the syntactic and pragmatic aspects of the language. It also calls for knowing how to read, write, and interact through computers. With the use of authentic resources such as computers as a means to write e-mails, learners become both writers and readers and are involved in authentic writing tasks found in everydaylife.

Another alternative to enhance communicative practice is to use in-house materials that have the potential to satisfy the specific needs of particular learners. However, as happens with textbooks, in-house materials have positive and negative aspects. Although it seems most teachers favor the use of textbooks in the language classroom, the truth is, as Ansary (2002) emphasizes, some teachers disregard them on the argument that no one textbook can respond to the different needs of each particular group of students. For this reason and others, some teachers dislike the idea of depending on published EFL textbooks. They prefer to 
use in-house materials. However, we might avoid being too radical and go for establishing a balance between the use of EFL textbooks and complementary materials.

English textbooks undoubtedly are valuable instructional material for teachers and learners alike. They include integrated skills appropriately, feature a progressive development of language forms and functions, and try to provide problem-solving activities. In addition, most English textbooks relate the language to the learners' own interests and aspirations, embrace cross-cultural topics, integrate language studies with other subjects, offer careful vocabulary based on semantic groups and context, and combine current teaching approaches to help learners use English fluently. In short, as English teachers, we can count on textbooks. Not only do they propose a well-organized and systematic progression in terms of the scope and sequence of contents and language skills; they also constitute a powerful guide to teaching practice. Certainly, there are good textbooks on the market that match teachers' instructional purposes with respect to communicative competence. Textbook E is one example; it offers good coverage in terms of meaningful and communicative practice and reduces the amount of mechanical activities. Nevertheless, English teachers must be conscious of the importance of complementing and enriching communicative practice by bringing extra authentic material into the classroom, particularly material that is not fully incorporated into the textbooks. Definitely, textbooks are not enough to enhance real communicative competence. As Graham Crookes states:

"The utility of the average textbook for a typical present-day ESL/EFL course is normally unquestioned. Nonetheless, we urge teachers to remember that most textbooks in a given period of time are often very much alike; they are the product of the pressures of market, as imperfectly interpreted through the publisher and materials writer, and can often run counter to legitimate educational pressures. What sells may not be what works; what works may not necessarily have a format which book publishing companies can utilize or produce" (2001:30).

In conclusion, teachers need to supplement EFL textbooks with extra material that is compatiblewith the particular situations found in language classrooms. The truth is that English teachers often continue to teach their classes with textbooks, because the teacher's guide provides all the methodological procedure, class activities, answer keys, and even the evaluations for each unit. So, it is not complicated for teachers to follow the suggested course of action. However, it is important to be clear about one aspect; namely, if the textbooks teachers implement for their instruction are highly communicative, there is a powerful reason to use them as the basis for teaching. Otherwise, it is important to take into account the results shown in this study. It is the teacher's responsibility to make cautious decisions when selecting textbooks for the classroom. Teachers also must be conscious of the types of practice (mechanical, meaningful, and communicative) textbooks frequently offer to learners, and must do what is needed to balance out meaning negotiation with supplementary materials that feature real-life situations, problem-solving tasks, authentic language use, and further communicative interaction.

\section{References}

Ansary, H. \& Babaii, E. (2002). "Universal characteristics of EFL/ESL textbooks: A step toward systematic textbook evaluation." The Internet TESL Journal for Teachers of English as a Second Language, VIII, 2, http://iteslj.org/ Articles/Ansary-Textbooks/

Backman, L. (1999). Fundamental considerations in language testing. Addison-Wesley Publishing Company, 81-109. 
Berry, R. (2000). “Use-ser' friendly metalanguage: What effect does it have on learners of English?” International Review of Applied Linguistics in Language Teaching, 24, 195-211.

Brown, H. Douglas (2006). Principles of language learning and teaching (5 $5^{\text {th }}$ Edition), Person ESL.

Brown, D. (2009). “Why and how textbooks should encourage extensive reading." ELT Journal, 63, 3, 238-245.

Bruton, A. (2002). "From tasking purposes to purposing tasks." English Teaching Language Journal, 56, 3, 280-288.

Byrd, P. (2001). "Textbooks: Evaluation for selection and analysis for implementation." In M. C. Murcia (Ed.), Teaching English as a second or foreign language (pp. 415-427). Heinle, Cengage Learning.

Canale, M. \& Swain, M. (1980). "Theoretical bases of communicative approaches to second language teaching and testing." Applied Linguistics, 1, 1, 1-47.

Crooks, G. \& Chaudron, C. (2001). “Guidelines for language classroom instruction.” In, M. C. Murcia (Ed.), Teaching English as a Second or Foreign Language (pp. 29-42). Heinle, Cengage Learning.

Dammacco, O. (2010). “Using 'Ttxt' to promote communicative language learning." The Internet TESL Journal for Teachers of English as a Second Language, XVI, 1, January. http://iteslj.org/Techniques/Dammacco-Text.html

Fromkin, V. \& Rodman, R. (2007). An introduction to language ( $8^{\text {th }}$ edition). Thomson.

González, A. (2006). “On materials use training in EFL teacher education: Some reflections.” Profile, Issues in Teacher' Professional Development, 7, ISSN 1657-0790, 101-115.

Hsiu-Chin, S. (2009). “The value of English picture story books.” ELT Journal, 62, 1, 47-55.

Kim, D. \& Hall, J. K. (2002). The role of an interactive book reading program in the development of second language pragmatic competence. Modern Language Journal, 86, 332-348.

Lázár, L., Denise, L., \& Peck, C. (2007). Developing and assessing intercultural communicative competence: A guide for language teachers and teacher education. European Centre of Modern Languages, Council of Europe.

Razmloo, S. (2007). "High schools or private institutions textbooks? Which fulfill communicative language teaching principles in Iranian context?" Asian EFL Journal: The EFL Professional's Written Forum, 9, 4, 126-140.

Richards, J. (2005). Communicative language teaching today. Cambridge: Cambridge University Press.

Richards, J. (1990). The language teaching matrix: Curriculum, methodology, and materials. Cambridge: Cambridge University Press. 
Richards, J. \& Rodgers, T. (2006). Approaches and methods in language teaching. Cambridge University Press. (11 ${ }^{\text {th }}$ printing.)

Roldan, A. \& Serrano, D. (2009). "Adecuación de los libros de texto al Marco Común Europeo de Referencia para las Lenguas (MCERL)." Porta Linguarum, 11, 189-206.

Savignon, S. (1985). Communicative competence: Theory and classroom practice. Reading: Addison-Wesley.

Savignon, S. (2001). "Communicative language teaching for the twenty first century." In M. Murcia (Ed.), Teaching English as a Second/Foreign Language (pp. 12-28). Boston, MA: Heinle \& Heinle.

Shekary, M. \& Tahririan, M. H. (2006). "Negotiation of meaning and noticing in text-based on-line chat." The Modern Language Journal, 90, 4, 557-573.

Skehan, P. (2003). “Task-based instruction.” Language Teaching, 36, 1-14.

Williams, D. (1983). “Developing criteria for textbooks evaluation.” ELT Journal, 37, 3, 251-255,

Council of Europe (2001). Common European framework of referencefor languages: Learning, teaching, assessment.

Table 1

\begin{tabular}{|c|c|c|c|}
\hline Textbook & $\begin{array}{l}\text { Number of units } \\
\text { analyzed }\end{array}$ & $\begin{array}{l}\text { Number of tables used } \\
\text { to classify activities }\end{array}$ & $\begin{array}{l}\text { Total \# } \\
\text { of tables }\end{array}$ \\
\hline A & 3 & 3 & \\
B & 3 & 3 & 15 \\
D & 3 & 3 & \\
E & 3 & 3 &
\end{tabular}


ISSN 0123-1294 | Educ.Educ. Vol. 13, No. 3 | Septiembre-diciembre de 2010 | pp. 327-346

Universidad de La Sabana | Facultad de Educación

\section{Table 2}

\begin{tabular}{|c|c|c|c|c|}
\hline Textbook & Unit & Mechanical activities & Meaningful activities & $\begin{array}{l}\text { Communicative } \\
\text { activities }\end{array}$ \\
\hline \multirow{4}{*}{ A } & 1 & $68.75 \%$ & $28.12 \%$ & $3.12 \%$ \\
\hline & 2 & $36.5 \%$ & $52.5 \%$ & $10 \%$ \\
\hline & 3 & $44.11 \%$ & $47.05 \%$ & $8.82 \%$ \\
\hline & Average $=$ & $50.12 \%$ & $42.5 \%$ & $7.31 \%$ \\
\hline \multirow{4}{*}{ B } & 1 & $30.76 \%$ & $50 \%$ & $19.23 \%$ \\
\hline & 2 & $43.3 \%$ & $40.37 \%$ & $16.66 \%$ \\
\hline & 3 & $39.13 \%$ & $40.6 \%$ & $30.43 \%$ \\
\hline & Average $=$ & $37.73 \%$ & $43.65 \%$ & $22.10 \%$ \\
\hline \multirow{4}{*}{ C } & 1 & $26.31 \%$ & $52.63 \%$ & $21.05 \%$ \\
\hline & 2 & $28.88 \%$ & $44.44 \%$ & $16.66 \%$ \\
\hline & 3 & $20 \%$ & $70 \%$ & $10 \%$ \\
\hline & Average $=$ & $28.39 \%$ & $55.69 \%$ & $15.90 \%$ \\
\hline \multirow{4}{*}{$\mathrm{D}$} & 1 & $54.16 \%$ & $25 \%$ & $21 \%$ \\
\hline & 2 & $52.17 \%$ & $26.08 \%$ & $21.73 \%$ \\
\hline & 3 & $39.13 \%$ & $34.78 \%$ & $26.08 \%$ \\
\hline & Average $=$ & $48.48 \%$ & $28.62 \%$ & $22.93 \%$ \\
\hline \multirow{4}{*}{$E$} & 1 & $6.66 \%$ & $66.66 \%$ & $26.6 \%$ \\
\hline & 2 & $10 \%$ & $50 \%$ & $40 \%$ \\
\hline & 3 & $14.28 \%$ & $47.61 \%$ & $38.09 \%$ \\
\hline & Average $=$ & $10.3 \%$ & $54.75 \%$ & $34.89 \%$ \\
\hline
\end{tabular}

Textbook A

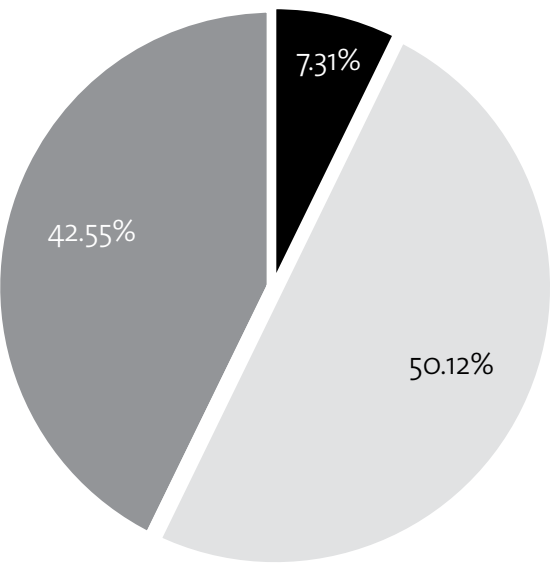

Communicative

Mechanical

Meaningful 


\section{Textbook B}

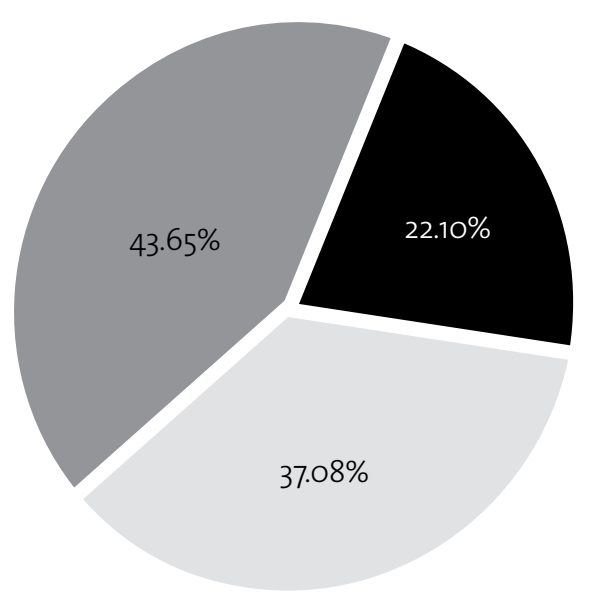

- Communicative

Mechanical

Meaningful

\section{Textbook C}

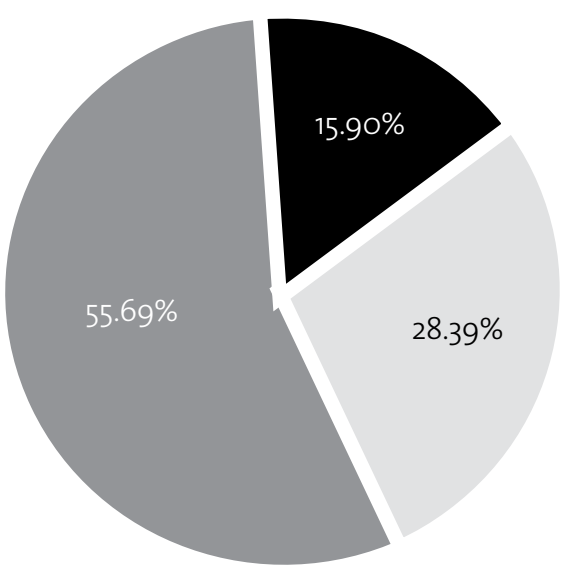

- Communicative

Mechanical

Meaningful 
ISSN 0123-1294 | Educ.Educ. Vol. 13, No. 3 | Septiembre-diciembre de 2010 | pp. 327-346

Universidad de La Sabana | Facultad de Educación

Textbook D
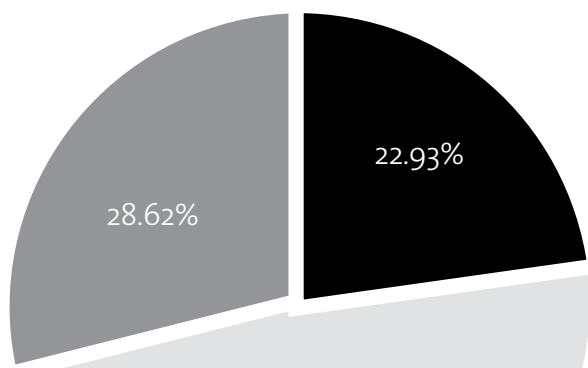

$48.48 \%$
- Communicative

Meaningful

Mechanical

\section{Textbook E}

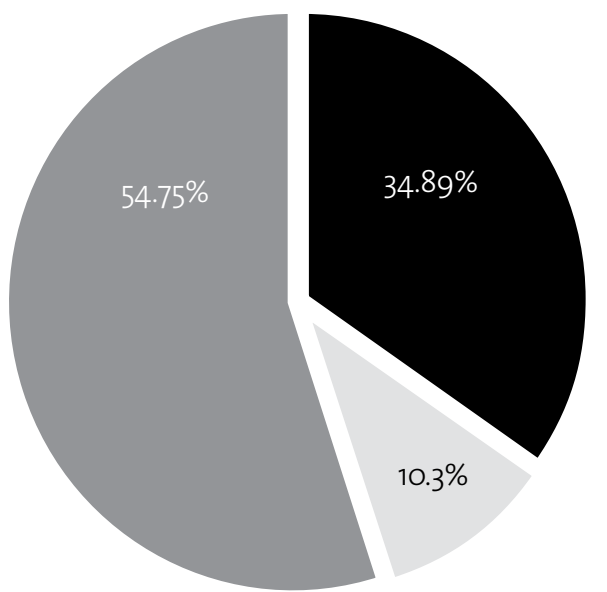

- Communicative

Meaningful

Mechanical

\section{Global Average for All the Textbooks}

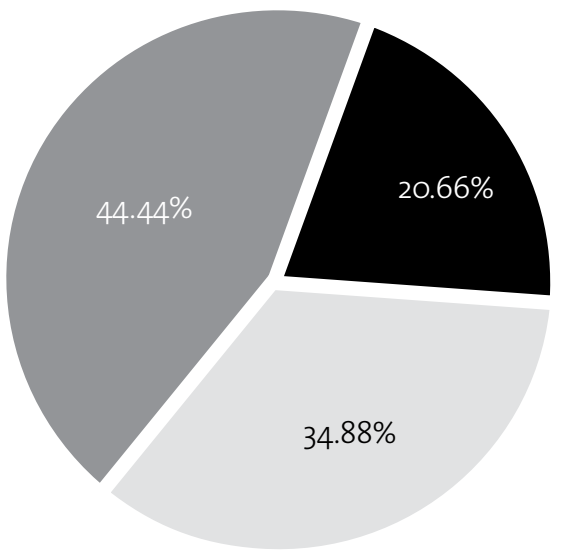

- Communicative

Mechanical

Meaningful 


\section{Language Skills, Grammar and Vocabulary}

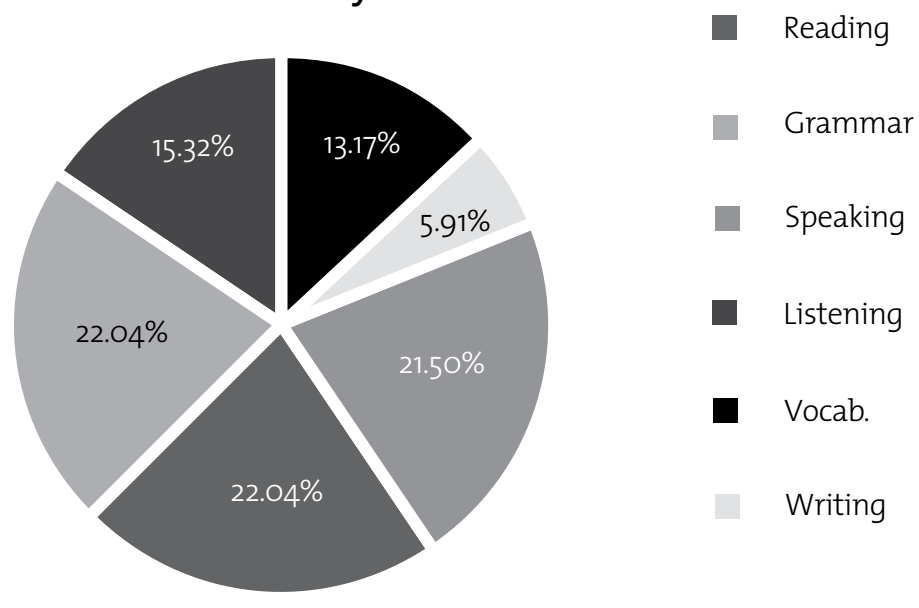

Table 3

\begin{tabular}{|c|c|c|c|c|c|}
\hline \multicolumn{2}{|c|}{ Mechanical practice } & \multicolumn{2}{|l|}{ Meaningful practice } & \multicolumn{2}{|c|}{ Communicative practice } \\
\hline Format & Average & Format & Average & Format & Average \\
\hline Repetition & $29.71 \%$ & Questions & $20.62 \%$ & Dialogues & $25.71 \%$ \\
\hline Grammar study & $21.01 \%$ & Matching & $15.62 \%$ & Writing letters & $17.28 \%$ \\
\hline Drilling activities & $18.11 \%$ & $\begin{array}{l}\text { Fill in the blanks by choos- } \\
\text { ing from several options }\end{array}$ & $15 \%$ & Open questions & $14.28 \%$ \\
\hline Fill in the blanks & $9.42 \%$ & Information transfer & $5.6 \%$ & Presentations & $7.14 \%$ \\
\hline Matching ${ }^{2}$ & $6.52 \%$ & Sentence formation & $5 \%$ & Fill in the gaps & $7.14 \%$ \\
\hline Others & $15.21 \%$ & Multiple choice & $37.5 \%$ & Others & $28.47 \%$ \\
\hline
\end{tabular}

2 With respect to mechanical practice, matching activities and filling in the blanks refer to those exercises not presented in context. The ones listed under meaningful practice are presented in context. 
ISSN 0123-1294 | Educ.Educ. Vol. 13, No. 3 | Septiembre-diciembre de 2010 | pp. 327-346

Universidad de La Sabana | Facultad de Educación

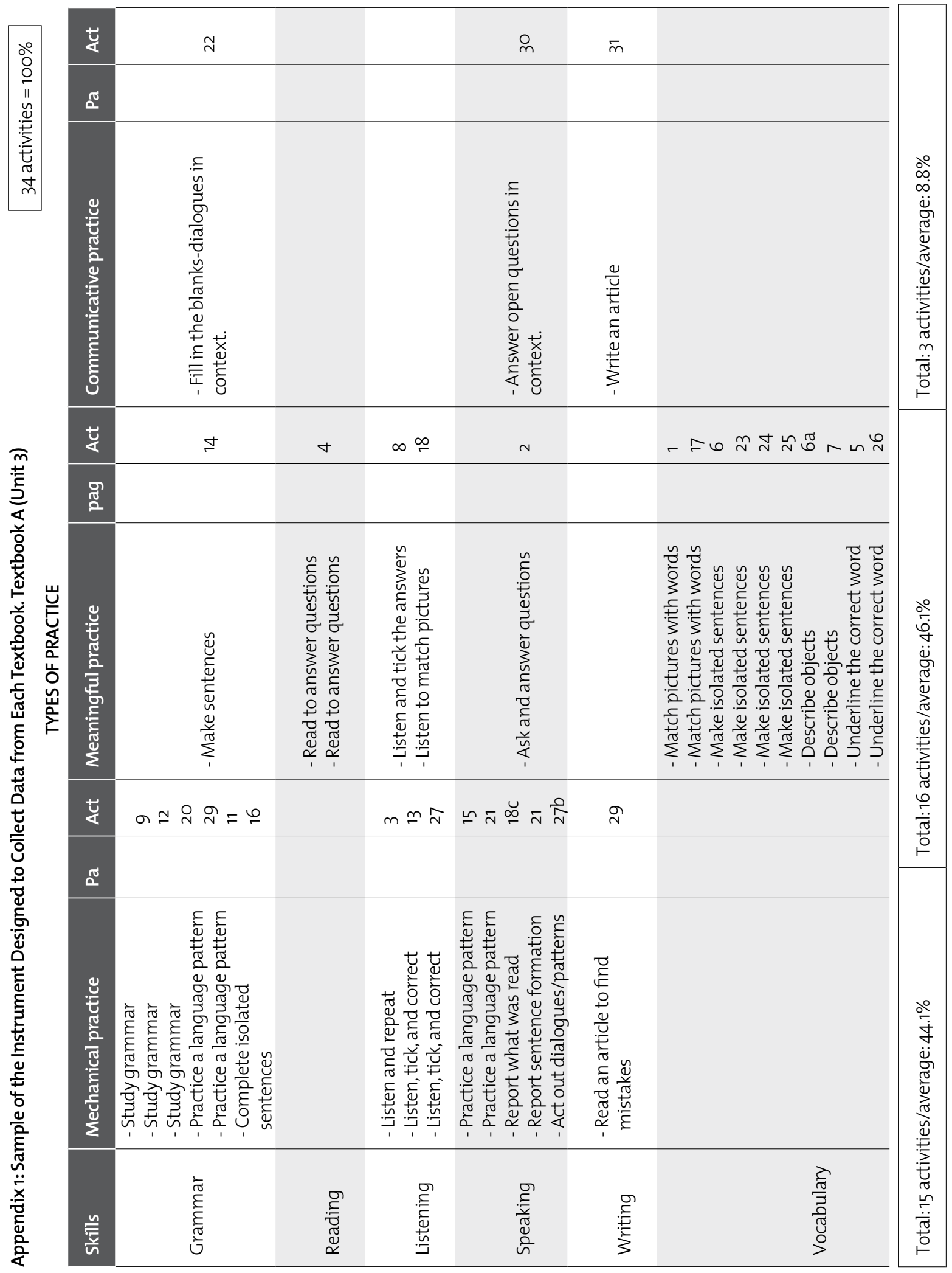

